\title{
German legal entities suitable for attorneys
}

\author{
by Frank Wooldridge
}

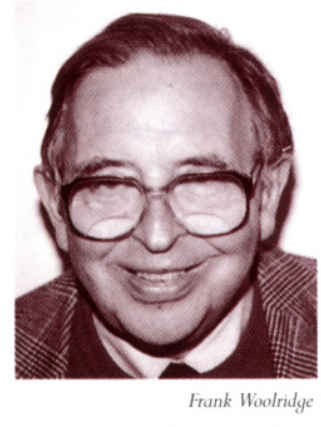

G erman Rechtsanwälte (RA) (attorneys) correspond to some extent to English barristers, and like the latter they may sometimes represent their clients before courts and other public authorities. Notaries (Notäre) exercise more limited functions than Rechtsanwälte, but in some Länder the two offices may be combined. Rechtsanwälte perform very diverse tasks and may for example act as in-house counsel, guardians of legally incompetent persons, trustees in bankruptcy and executors of wills. They are subject to certain rules governing their profession contained in the Bundesrechtsanwaltsordnung (BRAO - Federal Law Governing Attorneys) which is periodically revised. In addition, they are subject to subordinate legislation made thereunder, and also to the Rechtsberatungsgesetz (Law Governing the Giving of Legal Advice). Disciplinary control is exercised over them by special courts (Anwaltsgerichte).

Practices vary greatly in size. In recent years, there has been a tendency towards an increase in the number of persons involved in individual practices, which have occasionally taken on an international flavour. According to para. 59a of the BRAO, attorneys are permitted to practice in a multidisciplinary association (Sozietät) (a term meaning partnership rather than company) together with members of certain other professions, such as tax consultants and representatives, patent agents, professionally-qualified auditors and certified public accountants (verteidigter Buchprïfern). RAs may also practice in association with patent agents, tax consultants and representatives, and certified public accountants from other EC member states. As is emphasised below, the ability to enter into multidisciplinary relationships is somewhat restrictively regulated in the law of 31 August 1998 (BGBI 1998 1, 2600) making provision for the use of the private limited liability company (Anwalts-GmbH) as a medium through which attorneys may conduct a practice. The relevant restrictions are not applicable when the entity used is a civil law partnership or 'Partnerschaft'. The latter two types of entity may be used by persons who practisc diverse types of libcral professions, including attorneys.

The new Partnerschaft owes its existence to a law of 25 July 1994 (BGBI 1, 1744) generally called the
Partnerschaftsgesellschaftsgesetz, which was found to have certain defects, and which was amended by a law of 22 July 1998 (BGBI 1998 1, 1878). The small public company (Kleine Aktiengesellschaft) does not yet appear to be usepd by attorneys, although it might prove useful for them. As theirs is not a commercial activity within the meaning of para. 1 and 2, of the Commercial Code (Handelsgesetzbuch, HGB) attorneys in common with the members of other liberal professions cannot make use of the commercial partnership (offene Handelsgesellschaft) or the limited partnership (Kommanditgesellschaft, $K G$ ). Although the $\mathrm{KG}$ does not resemble the American LLP, which has had a considerable influence on recent English thinking concerning limited liability partnerships, the KG has undergone interesting and sophisticated developments in Germany which have made it a very flexible vehicle for business undertakings but which are beyond the scope of this article.

The choice of the legal form under which a particular practice is conducted will depend upon the particular needs of the practice. It may well transpire that the popularity of the Partnerschaft and the Anwalts-GmbH will tend to increase and that the civil law partnership (Gesellschaft des bürgerliches Rechts, GbR) may become of less importance. It has been suggested that certain civil law partnerships may convert themselves into one of the two other available forms. However, although the GbR has certain disadvantages, it has been used in recent years not only for the purposes of small groups of attorneys but also for very large firms of attorneys with a considerable number of partners, organised on a regional or more comprehensive basis.

\section{THE CIVIL LAW PARTNERSHIP}

\section{Nature and governing rules}

Before the two new entities came into being, attorneys and other members of the liberal professions had to make use of the civil law partnership in order to conduct a practice. Under German law every group of persons associating together to pursue a common purpose without making use of the commercial or limited partnership, or one of the three forms 
available under company law, is treated as being such a partnership. As is the case with an English partnership, such a partnership may come into being by means of an unwritten agreement. The partnership is governed mainly by para. 705-740 of the Civil Code. There are few compulsory provisions apart from those governing duration and liquidation.

\section{Apparent defects}

The civil law partnership would appear to have a number of defects from the point of view of persons engaged in the liberal professions, including attorneys. German text writers generally agree that it lacks a clearly defined legal structure, and although some have argued to the contrary, the consensus of opinion scems to be that it lacks legal capacity (see Berndt/Boin, Zur Rechtsnatur der Gesellschaft bürgerliches Rechts NJW 1998, p. 2854). In addition, such a partnership cannot enter into transactions, acquire obligations, or sue or be sued in its own name. Frequently, difficulties arise in finding out whether and to what extent the individual partners are liable to third partics. The view is generally taken that where there is a managing partner, his power of representation may be so limited that he is only allowed to enter into obligations which may be enforced against the partnership property and not against the individual partners. Such a limitation may be included in an express provision of a contract with a managing partner, but it is sufficient if it appears on the partnership notepaper (Briefbogen) (NJW 1985, 619 and 1846). This requirement may not be very desirable in the case of a professional partnership, especially one between attorneys. However, partnerships between attorneys may also take advantage of the limitation of liability contained in para. 51a (2) of the BRAO. This provides that members of such partnerships may limit their liability for damages by means of standard contractual clauses, to those members of the partnership who worked on a brief on areas within their competence and who are specifically mentioned by name. A declaration of consent by the client to such a clause is necessary, and it must not depart from its terms. Such a declaration may, of course, not always be forthcoming, but this facility may sometimes prove useful.

The civil law partnership is still used to a considerable extent, and by the largest German business law firms in Germany, despite the availability of new forms. This is partly because conversion of a GbR to a Partnerschaft or an Anwalts-GmbH would require an alteration of the accounting system and thus might impose a considerable burden on the new entity during the first year of its life. The Clifford Chance Pünder sub-partnership, for example, takes the form of a civil law partnership.

\section{THE 'PARTNERSCHAFT'}

\section{Nature and participation}

The first new entity to be introduced was the Partnerschaft, now governed by the statute of 1994 (Partnerschaftsgesellschaftsgesetz, Part GG) which underwent significant amendment in 1998. The statute mercifully contains only eleven paragraphs. Paragraph 1(1) provides that a Partnerschaft is an association in which persons carrying on liberal professions combine in order to exercise their profession together. It does not carry on a commercial enterprise, and members may only be natural persons. Thus a Partnerschaft between attorneys or other professionals could not belong to another such Partnerschaft, and would be required to choose some other medium for any co- operation felt necessary. If some extra-territorial element was present in such co-operation this might be through the medium of a European Economic Interest Grouping.

Paragraph 1(2) is of as much sociological as legal interest. It attempts a general definition of the characteristics which the liberal professions have in common and gives a very exhaustive enumeration of activities which involve the exercise of a liberal profession within the meaning of the statute. These activities include those of such diverse persons as attorneys, patent agents, doctors, alternative practitioners, midwives, pilots, economic advisers, translators and interpreters. In the past many such activities have not been treated as being liberal professions.

According to para. 1(3), the exercise of a liberal profession by means of a Partnerschaft can be excluded or made subject to additional requirements according to the laws governing particular professions. Inter-professional co-operation may sometimes be prevented or inhibited by such laws, as also by long-standing rivalries. The relevant provisions of para. 59a of the BRAO relating to attorneys have been discussed above.

According to para. 1(4), the rules continued in the Civil Code governing the GbR are applicable to the Partnerschaft except where the 1994 statute provides otherwise. It will be noted that the latter often makes reference to the Commercial Code.

\section{Name}

Paragraph 2 of the Part GG requires the name of the Partnerschaft to contain the surname of at least one partner, together with the suffix 'und Partner' or Partnerschaft and an indication of the professions represented. In the case of the withdrawal of a partner whose name forms part of the firm's name, the express consent of such partner or his heirs will be required for the continuation of the firm's name.

\section{Form of the partnership agreement}

The partnership agreement must be in a written form and include certain prescribed particulars (para. 3). These are the name and the principal place of business, the names and addresses of the partners, and their full professional activities.

\section{Registration and its effect}

The formation of the partnership has to be entered in the Partnerschaft register (which is distinct from the Commercial Register) maintained by the local commercial court, together with the prescribed particulars mentioned immediately above (para. 4). A Partnerschaft (unlike an Anwalts-GmbH) is not a legal person, but rather a community of partners. However, it may acquire rights or obligations, bring or defend actions in its own name and be entered in the Grundbuch as the owner of property, after having been entered in the Partnerschaft register (para. 7(1)).

\section{Internal structure}

Each partner is required to excrcise his profession independently and autonomously, having regard to the legal rules governing it. This rule contained in para. 6(1) is designed to prevent a partner from accepting instructions from another, especially one excrcising a different profession in a multidisciplinary partnership. According to para. 6(2), the partnership agreement may exclude a partner from carrying out 
particular transactions, but cannot exclude him entirely from the management of the partnership's affairs. The relationship between the partners is governed by the partnership agreement and, where this contains no relevant provisions, by certain provisions of the Commercial Code (para. 6(3))

\section{Representation}

The representation of the Partnerschaft in relation to third parties is governed by para. 125(1), (2) and (4), 126 and 127 of the Commercial Code (Part GG, para 7(3)). Each partner is thus authorised to represent the partnership, but the partnership agreement may provicle that all or several partners shall only have the power to represent the partnership jointly. As is the case under 37(2) of the Law Governing Private Limited Liability Companies, such a limitation has no effect as against third partics.

\section{Liability for obligation}

Paragraph 8, which concerns liability for the obligations of the Partnerschaft, is perhaps the most important provision of the statute. According to para. 8(1), the creditors of the Partnerschaft not only have access to its assets in satisfaction of their claims, but the partners therein are jointly and severally liable to them in respect of such claims. It also provides that para. 129 and 130 of the Commercial Code apply by way of analogy. The former paragraph contains rules governing defences against a claim. Paragraph 130, which contains a different rule from that governing the civil law partnership in the present matter, provides that a person who joins an existing partnership has the same liability as the other partners for the obligations of the partnership incurred before his entry thereto.

Paragraph 8(2) of the Part GG, which underwent fundamental amendment in 1998, provides that where only certain partners are involved with the performance of a task, the latter alone are jointly and severally liable to the clients for professional clefault. The latter also have recourse to the partnership's assets. In order to benefit from the limitation of liability contained in para. 8(2), a partnership will be well aclvised to ensure that it is always clear to clients which partners have carried out the transaction on its behalf. Paragraph 8(2) also stipulates that the rule explained above does not apply to work done of secondary importance. The meaning of this provision is somewhat unclear, but it seems that it may, for example, relate to work done by a partner when a colleague is absent on holiday, on a short leave, or through indisposition. The 1994 statute does not make provision for any liability to arise through the inadequate supervision of other partners, as do certain US LLP statutes. Such liability might however arise as the result of para. 278 of the Civil Code.

According to para. 8(3) German statutes may provide for the limitation of liability in certain professions up to a specified amount in respect of professional default, provided that such statutes also require the imposition of an obligation to insure on the partners or the Partnerschaft. It is perhaps surprising that the obligation to insure is not imposed both on the partners and the Purtnerschaft. Certain German statutes already take a similar approach. Thus attorneys are required by para. 51 of the BRAO to insure against professional liability, and a limitation of liability is available to them under para. $51 \mathrm{a}(1)$ No. 2 BRAO. According to this provision, standard contractual terms may limit their liability for simple negligence to four times the minimum amount insured, provided that insurance cover exists.

\section{Dissolution and withdrawal}

The provisions of para. 9 concern the dissolution of, and withdrawal from the Partnerschaft. Paragraph 9(1) provides that the provisions of para. 131-144 of the Commercial Code applicable to the dissolution of, and withdrawal from a commercial partnership shall apply to the Partnerschaft except where the governing statute otherwise provides. Thus it is clear that any partner may require the dissolution of the partnership without notice by a judicial decision if there is an important ground therefore. It may be the case that the expulsion of a partner is only possible if the court so orders on the petition of the other partners (para. 140 and 142, Commercial Code).

\section{Inheritance of shares}

As the Partnerschaft is intended as a medium for carrying on liberal professions (understood in a wide sense), it is hardly surprising that para. 9(4) no 1 of the Part GG contains the rule that shares in a partncrship are not inheritable. However, the statutes of a Partnerschaft may provide that an heir who satisfies the requirements for membership may inherit a share therein. Nothing is stipulated in the Part GG (as amended) about the situation where a share is left to a legatee who is qualified for membership. It is not clear what is intended to happen if a share in a Partnerschaft is transferred to an unqualified person, perhaps with the consent of all the other partners. The view has been taken that such a transfer is a nullity until such time as the Partnerschaft is converted into a GbR (K Schmidt, 'Die freibüfliche Partnerschaft', NJW 1995 1, 2).

\section{Liquidation}

According to German law, liquidation is a process which follows dissolution. The provisions of the German Commercial Code which relate to the liquidation of commercial partnerships are treated by para. 10 of the Part GG. It follows from para. 159 of the Commercial Code that claims against a partner based on the obligations of the partnership are barred by prescription five years after its dissolution, except insofar as the claim is not subject to a shorter prescription period. Claims against a partner who has withdrawn are governed by the rather similar rule contained in para. 160 of the Commercial Code.

\section{Certain transitional rules}

The transitional rules contained in para. 11 were mainly relevant to the GbR. If an entity had made use of the designation Partner or Partnerschaft, it was only permitted to continue to do so for a period of two years after the entry into force of the Partnerschaftsgesellschaftsgesetz. After this period of time (which ended on 1 March 1997), the use of such a designation was only permitted if an indication of the legal form of the entity was also given.

It is understood that more practical use has been made of the Partnerschaft since the changes in the law in 1998.

\section{THE ANWALTS-GMBH}

It was long disputed whether attorneys could make use of a $\mathrm{GmbH}$ (private limited liability company) for the purpose of 
excrcising their profession. It was contended by certain of the professional bodies that the use of a limited liability company by attorneys would lead to a commercialisation of their activities and might cause them to take insufficient account of the requirements of professional ethics. Furthermore, it was also contended that if attorneys were members of a company their independence might be compromised. Both these two contentions appear to fail to take into account the fact that Anwalts-GmbH could be made subject to special professional or other rules safeguarding, inter alia, the independence, and governing the conduct, of attorncys exercising their profession through the medium of such companics. In 1993, the Supreme Court held that dentists could make use of the $\mathrm{GmbH}$ for the purpose of exercising their profession (BGHZ 124, 224)

The Regional Appeal Court of Bavaria came to a similar conclusion about attorneys in its decision of 24 November 1994 (NJW 1995, 199). This court held that attorneys could make use of a $\mathrm{GmbH}$ for the joint exercise of their professional activitics. In reaching this conclusion it was much influenced by art. 12 of the Federal Constitution, which provides, inter alia, for freedom to cxercise a profession. The court then held that an Anwalts$\mathrm{GmbH}$ was always capable of being cntered in the Commercial Register, provided that its statutes contained the necessary minimum requirements to safeguard the independence of the attorneys. After this decision, a considerable number of Anwalts$\mathrm{GmbH}$ were formed and, on some occasions, provisions in their statutes were considered by the ordinary civil courts and by the specialist professional courts (Anwaltsgerichte).

The preliminary draft of a law governing the Anwalts-GmbH was published in 1997; it contained certain provisions which would probably have had a restrictive effect on the new entity, and after some adverse comment by professional bodies many of these provisions were removed in the Ministry of Justice's final draft. The new provisions concerning the Anwalts-GmbH are contained in a law of 31 August 1998 (BGBI 1998 1, 2600) which amends the Bundesrechtsanwaltsordnung (BRAO, Law Governing Attorncys), the Patentsanwaltsordnung (Law Governing Patent Attorneys), and certain other statutes. The relevant provisions included in the BRAO concerning Rechtsanwaltsgesellschaften are para. 59c-59m. These provisions came into force on 1 March 1999. In addition to these provisions, the Law Governing Private Limited Liability Companies of 1892 , as subsequently amended, is applicable to such companies except where the law otherwise provided.

\section{Formation, membership and registration}

Special official approval has to be given to the formation of an Anwalts-GmbH before it can be entered on the Commercial Register kept by the local commercial court. This requirement avoids placing an extra burden on the local court which would otherwise have to examine matters relating to professional qualifications. The required consent is given by the Regional Ministry of Justice in the particular Land or receiving an opinion from the exccutive board of the local attorneys' chambers (Rechtsanwaltskammer) as to whether the requirements of para. 59d BRAO have been complied with. These are that the provisions of para. 59c, 59e and 59f have been satisfied by the relevant company, that it is not in a scrious financial situation (Vermögensverfall), and that the obligation to insure has been satisfied, or that an interim cover note has been obtained.
The objects of the company must be to give legal advice and to represent clients (para. 59c). Its members may only belong to a restricted range of legal professions, i.e. Rechtsanwälte, tax consultants and representatives, auditors, certified public accountants, or patent agents. Attorneys (Rechtsanwältc) who are also notaries may be members, but may only exercise that function as attorneys within the company. Notaries are legally qualified persons who perform such functions as drawing up documents, and officially certifying certain transactions.

The shareholders are prohibited from exercising the activity which they pursue in the Anwalts-GmbH in any further professional combination (Zusammenschluss) (para. 59e(2)). This rule would not seem to prevent them from taking a purely passive role in such an entity. The majority of the shares and the votes must belong to attorneys. Both the two latter provisions have been, it would seem correctly, stigmatised as unduly restrictive (see Henssler, 'Die gesetzliche Regelung des Rechtsanwalts-GmbH', NJW 1999, 241, 244-6)

The majority of the managers of the company must be attorneys (para. 59f(1) BRAO), and all of them must belong to one of the liberal professions already indicated. According to para. 59f(3)BRAO, the same principle applies to authorised signatories with full powers of representation (Prokuristen) and to managing agents for the whole firm (Handlungsberollmächtigten). The requirement that the company must not be in serious financial difficulties (Vermögensverfall), would only seem applicable where a GbR or a Partnerschaft was being converted into an Anwalts-GmbH or an already existing $\mathrm{GmbH}$ was changing its objects so as to become one, if a new Anwalts-GmbH was being formed, the requirement of conformity with the rules contained in the GmbH Gesetz concerning capital contributions should make the registration of a company having serious financial difficulties virtually impossible (see Henssler, 'Dic gesetzliche Regelung der Anwalts-GmbH', NJW 1999, pp.241, 243).

The official consent to the formation of the company may expire, be withdrawn or revoked under the conditions laid down in para. 59h BRAO.

\section{Name}

The name of the company is required to contain the name of at least one sharcholder who is an attorney, as well as the designation Rechtsanwaltsyesellschaft, and may contain certain other legally permissible component parts. If the company is the continuation in being of a former association ( $G b R$ or Partnerschaft), it may make use of a permissible abbreviation in addition to, or in substitution for, the name of the momber. Such an abbreviation may consist of the surname of one of the senior partners in the pre-existing firm, but not, apparently, simply his or her initials. (Para. 59k BRAO).

\section{Transfer and transmission of shares}

According to para. 15 of the GmbH (Law Governing Private Companics), shares in a private company are frecly transferable. The members of such a company may, and often do, impose restrictions on such transfer. However, no such restriction is necessary in the case of an Anwalts-GmbH, because such transfers would have to be to members of one of the professions capable of participating in such a company. If a transfer took place to any other person, it would seem to be a nullity. In addition, it would 
lead to a situation in which consent to the formation of the company might be revoked (para. 59h No.1 BRAO). If shares in an Anwalts GmbH are transmitted to an heir who is not qualified to be a member, it follows from para. $59 \mathrm{~h}$ (3) No. 2 BRAO that the company has one year following the inheritance in which to regularise the situation.

\section{Management}

There is (as alreadly indicated) no need for all the members of the company to become managers. Those members of the company who are not managers are likely to have an employment relationship with it. It follows from para. 59f (4) BRAO that the independence of attorneys, and the managers or authorised agents (in accordance with para. 59f(3)) in exercising their professional duties has to be respected. Instructions may not be given to them concerning the exercise of their cluties.

The Anwalts-GmbH must have chambers at its principal place of business in which at least one responsible manager is active and for whom the chambers represent the focal point of his work. The same rule is applicable to branches.

\section{Representative capacity}

An Anwalts-GmbH can be empowered to act as an authorised representative before the courts and other authorities. In such a case, it has the rights and obligations of a attorney. It acts through the medium of its organs and representatives who fulfil the necessary statutory requirements for the provision of services in the particular instance. The defendant in the sense meant by para. 137 et al of the Criminal Procedure Code is the person acting on behalf of the Anwalts-GmbH (para. 59l).

It appears to have been necessary to enact the above provisions because it has been much disputed in the literature whether legal persons could be empowered to act in a representative capacity before the courts. The Anwalts-GmbH is now granted considerable scope to do so. However, it still appears that capital companies (which include the $\mathrm{GmbH}$ ) cannot provide legal services in the fields of bankruptcy and insolvency administration.

\section{Requirements governing insurance}

The requirements placed on the Anwalts-GmbH concerning insurance, contained in para. $59 \mathrm{f} \mathrm{BRAO}$, are somewhat stringent and, like the restrictive ones concerning a multidisciplinary partnership mentioned above, have some unfortunate features. An Anwalts-GmbH, is required to insure against professional liability and to maintain such insurance during the period of time in which it is officially authorised to carry on its activities. The minimum amount insured consists of DM $5 \mathrm{~m}$ for each claim (Versicherungsfall). The premiums which have to be paid to the insurer in respect of all the prospective losses arising within the insurance year must cover the minimum amount insured multiplied by at least four. If the number of members and managers of the company who are not members thereof exceeds four, the minimum amount insured must instead be multiplied by this total. These requirements may possibly impose a disproportionate burden on Anwalts-GmbH; the account of the actual claims against such entities may not justify such a burden even though Rechtsanwälte (unlike English barristers) are subject to strict standards of professional liability under German law in respect of their consultancy, court and other work.

The sole practice, GbR and Partnerschaft have received favourable treatment in insurance matters compared with the Anwalts-GmbH. This may be partly because German attorneys retain some justified suspicion of private limited liability companies, which have sometimes been used as vehicles for fraudulent transactions in the past.

If the duty to insure is not fulfilled, or insurance does not take place for the prescribed amount, the company together with its shareholders and managers will be liable for the default (para. $59 \mathrm{j}(4))$. It remains to be seen whether the insurance requirements will have an inhibiting effect on the formation of Anwalts-GmbH. Although they have been made use of by attorneys, the latter seem to have made more use of the Partnerschaft recently.

\section{Conclusion}

All the forms of entity described in the present article would seem to have some defects. Certain of those from which the Partnerschaft used to suffer have been removed by the law of 31 August 1998, and it would seem likely that the Anwalts-GmbH will eventually become the subject of amending legislation. Any proposals to amend the rules governing the civil law partnership might, because of their antiquity, give rise to considerable controversy. However, even in its present form this entity is likely to remain of considerable utility, despite its defects. The Partnerschaft and the Anwalts-GmbH are likely to increase in popularity, especially when the rules governing these entities become more familiar, and their merits and defects more apparent. The legal form which a particular practice adopts will depend on its particular requirements, and such matters as the impact of the rules contained in the BRAO and elsewhere governing, for example, multidisciplinary co-operation and insurance against professional liability in the particular circumstances. Taxation considerations are also important. Some take the view (see Rommerman, Anwalts-GmbH in Wettbewerb', GmbH Rundschau 1998, pp. 966, 968) that certain large firms of attorneys might with advantage make use of the small public limited liability company (kleine Aktiengesellschaft) in respect of which special legal rules were enacted in 1994 (BGBI 1994 1, 1961). Such companies are undefined, but it seems that they will frequently be subject to less onerous publicity requirements than larger public companies (para. 267(1), Commercial Code). The managerial structure of such companies might be more clearly defined and thus more suitable for large firms than that of the Anwalts-GmbH and it appears that such companies are already used by auditors (Wirtschaftsprüfern).

\section{Frank Wooldridge \\ University of Notre Dame, London}

The writer would like to thank Mr R Bärwaldt of Clifford Chance Pünder, Berlin, for his help with certain practical points of German law. 